\title{
Factors Associated with Non-Use of Contraceptives among Married Women in Nepal
}

\author{
Ramesh Adhikari, $\mathrm{PhD}^{\mathrm{I}}$ \\ Devaraj Acharya², Chhabi Lal Ranabhat, $\mathrm{PhD}^{3}$, Ranju KC4,
}

\begin{abstract}
Most of the family planning services are being provided free of cost in Nepal however the rate of service utilization appearsunsatisfactory. This paper aims to assess the factors that are associated with non-useof family planning servicesamong currently married women of reproductive age.The data for this paper are extracted from theNepal Demographic and Health Survey (NDHS), 2016.Altogether 9875 currently married women of reproductive age wereincluded in this analysis. Bivariate and multivariate analysis were performed to explore the association of socio-demographic characteristics with non-use of contraceptives. Almost a half of the sampled currently married women (47\%) were non-users of contraception. Married women aged below 25 years $(\mathrm{aOR}=2.07,95 \% \mathrm{Cl} \quad 1.75-2.44)$ and aged 25 to 34 year $(\mathrm{aOR}=\mathrm{I} .15,95 \% \mathrm{Cl}$ I.02-1.29) were more likely to not to use contraceptives compared to women aged 35 or above years. Janajati were less likely to be non-user of contraception compared to Brahmin/Chhetri (aOR=0.73, 95\% Cl 0.64-0.83). Muslim women were less likely to use contraception $(\mathrm{aOR}=2.45,95 \% \mathrm{Cl}$ 1.9-3.2) compared to Hindu women.Likewise, women who did not work currently were more likely to not use contraceptives compared to currently working women $(\mathrm{aOR}=\mathrm{I} .47,95 \% \mathrm{Cl}$ I.32-1.63).Similarly, poor women were less likely to not use contraception compared to rich women $(\mathrm{aOR}=\mathrm{I} .15,95 \% \mathrm{Cl} \mathrm{I.0I}$ I.32).Similarly, women who had no autonomy were more likely to be non-user of contraceptive $(\mathrm{aOR}=\mathrm{I} .16,95 \% \mathrm{Cl} \mathrm{I} .0 \mathrm{I}-\mathrm{I} .32)$ than those how had high autonomy. Women who had not heard family planning message from TV in last few months were more likely to not use contraceptives $(\mathrm{aOR}=1.16,95 \% \mathrm{Cl} I .02-1.3 \mathrm{I})$ than those who had heardafter controlling other socio-economic variables. Women aged less than 25 years, Muslim women, currently not working and having poor wealth status, having no autonomy in household decision making, who did not watch FP message in TVwere more likely to not use contraceptive methods compared to their counterparts. Thus, family-planning-related interventions need to be more focused among younger aged women, women having no or less autonomy in decision making, poor and jobless women and Muslim women. Furthermore, women empowerment initiatives (employment opportunities) tied up with family planning programs would be beneficial to increase contraceptive uptake among married women of reproductive age.
\end{abstract}

Keywords: Contraceptives, family planning, married women, socio-demographic characteristics

\section{Introduction}

Despite the various efforts of the Government of Nepal [GoN] and other stakeholders, the utilization of family planning [FP] services isnot sosatisfactory although they are available free of

\footnotetext{
${ }^{1}$ Corresponding Autohor, Ramesh Adhikari, Associate Professor, MahendraRatna Campus, Kathmandu Email: rameshipsr@gmail.com

${ }^{2}$ Lecturer, Bhairawa Campus, Bhairahawa Multiple Campus, Rupandehi

${ }^{3}$ Policy Research Institute, Kathmandu

${ }^{4}$ Center for Research on Education Health and Social Science (CREHSS), Kathmandu
} 
cost (Department of Health Services [DoHS], 20I8). Data from the latest survey report shows that more than a half $(53 \%)$ of currently married women of reproductive age had used FP method, of whom43 percent and 10 percent had used modern and traditional method respectively in 2016(Ministry of Health; New ERA; \& ICF, 2017).Many women from developing countries use contraceptives to prevent unplanned and unwanted pregnancies. Data show that there has been a gradual increase in utilization of contraceptives from 10 to 50 percent between the 1960s and the 1990s (Korra, 2002). Regardless of the enormous benefits of family planning services, their utilization still remains low in developing countries resulting into high rates of unwanted pregnancies, unplanned deliveries, unsafe abortions and maternal mortalities (Chaudhary, Dangol, Rai, \& Rai, 2016). The Nepal Demographic and Health Survey [NDHS] 2016 shows that after an impressive increase in national contraceptive prevalence rate (CPR) in use of modern methods from 26 percent in 1996 to 44 percent in 2006, there has been no increase over the past 10 years; CPR remaining stagnant at 43 percent from $201 \mathrm{I}$ to 2016 . The CPR varies with age from 23 percent among currently married women aged 15- 19 to 69 percent among women aged 35-44. Modern contraceptive use peaked at 58 percent among currently married women aged 40-44 and then declined slightly to 56 percent among women age 45-49(Ministry of Health; New ERA; \& ICF, 20I7).

The International Conference on Population and Development [ICPD]in Cairo, Egypt in 1994 declared a key message on fertility reduction at any cost to ensure human right for women (Sutherland, 1994) and the Constitution of Nepal, 2015 has also offered 'right to live with dignity, right to safe motherhood and reproductive health; and equal access to health services' to all citizen including women (Nepal Law Commission, n.d.). Various activities were being implemented for ensuring the right of women by the GoN however output was below the expectation despite making various regular efforts. NDHS, 2016 shows that 24 percent of the married women had an unmet need for FP, i.e. women want to delay or limit their childbirth but they are not using any contraception. Similarly, nearly 60 percent of the users discontinued the FP method they adopted(Ministry of Health; New ERA; \& ICF, 20I7). CPR of modern method of contraception was 44 percent in the fiscal year 2073/74 eventhough the FP services are being delivered from hospitals, primary health centres, health posts, outreach clinics, other community-based and charity-based clinics/hospitals and Female Community Health Volunteers [FCHVs](Department of Health Services, 20I8).

Appropriate use of contraceptive prevents unwanted birth, protects the health of mother and child and promote well-being of women(Health Policy Project, n.d.). The World Bank (2015) claims that one in every 200 women die from pregnancy and or delivery related health problems in Nepal (Health Policy Project, n.d.). Family planning is not only issue of women's right rather indicator of gender equality, child health, education as well as one of themeans of poverty reduction (Ministry of Health; New ERA; \& ICF, 20I7). High rates of CPR indicate not only the positive health but a symbol of prosperity and development. The Family Health Division [FHD] under the DoHS is mainly responsible to meet the goal of FP programme and various govermental and non-governmental organizations are also supporting FHD to meet the targets as per the national and international commitments made by GoN. The main aim of the FP programme is to increase the access to quality health service including FP services without fiancial hardship (GoN/DoHS, 20I8). 
A hospital-based study conducted at Nepal Medical College Teaching Hospital in 2008 shows that out of 200 surveyed women,78 percent were aware about Depo Provera, followed by pills (74 percent), and condoms (7I percent). Side effects were the main cause of non-use and discontinuity of contraceptives(Tuladhar \& Khanal, 2008). Similarly, the NDHS2016 shows that almost all respondents had knowledge about FP methods. Almost all surveyed women ( 99 percent) had knowledge about injectables followed by female sterilization (98 percent), condoms (96 percent)and oral contraceptives (93 percent)(Ministry of Health; New ERA; \& ICF, 2017).

\section{Methods}

Data for this secondary-research paper were drawn from Nepal Demographic and Health Survey (NDHS, 2016). The 2016 NDHS, anationally representative sample survey, provides upto-date andreliable data on fertility and family planning, child mortality, children's nutritional status, utilization of maternal and child health services, domestic violence, and knowledge of HIV/AIDS. The 2016 NDHS was carried out under the aegis of the Population Division of the Ministry of Health and Population.A set of validated questionnaires was used to collect the information from married women of reproductive age. Verbal consent was taken prior to interview from repsondents. The study protocol was reviewed and approved by Institutional Review Board in Maryland, USA and Nepal Health Research Council. Data were collected during 19th June 2016 to 3 Ist January 2017 (Ministry of Health; New ERA; \& ICF, 20I7).

The required samplesize for the NDHS was calculated based on National Census 201I implemented by Central Bureau of Statistics [CBS] Nepal as per the rule of statistics and representativeness of the country by selecting urban-rural, provinces including geo belts. Altogether 12,862 women of reproductive age [15-49 years] were interviewed. This paper selected 9875 currently married women as the sample population. There were six different questionnaires, including the women questionnaire [WQ]. The variables included in the WQ were related to background characteristics, preganancy, family planning, fertility, natal care, breast feeding,immunization and childhood illness, women's employment status and husband's characteristicsand domestic voilence.Details of survey methodology can be obtained from NDHS report (Ministry of Health; New ERA; \& ICF, 20I7).

The independent variables were women's autonomy in household decision, age group, ethincity, education, religion, province, place of living, desire for children, information about family planning, currently working and wealth status of the respondents whereas family planning was the dependent variable. Univariate, bivariate and multivariate analysis were applied to the data. Initially, univariate or descriptive analysis was used to describe the respondents' socio-demographic characteristics. Bivariate analysis was performed to show the association between dependent and independnet variables. Then, after controlling for the socio-demographic and economic variables, multivariate analysis in the form of logistic regression was used to identify whether independent variables affected the women'slikelihood of not using contraception. Three logistic regression models were usedin the analysis. For the analysis, statistical software, SPSS version 20 was used.

\section{Results}

Background characteristics of women of reproductive age group

More than a fourth women had no autonomy in household decision making (Table I). Almost a fourth of them were aged 15-24. About a thirdof them were Janajati followed by 
Brahmin/Chhetri. Two out of the five women had no formal education. An overwhelming majority of the women followed Hinduism. More than a fifth women lived in Province 2 (higher than in other provinces). Two-fifth of the women resided in rural areas. One out of seven women wanted more children after 2 years followed by ten percent desiring more children within 2 years. Two-third of the women were currently living with their husband.

Only a third of the women had heard about family planning from radio (34\%) and TV (33\%) in the last few months. Similarly, just over 10 percent of the women (1 I\%) have heard of FP from newspapers/magazines in the last few months. Three out of the five women $(60 \%)$ were currently working. Nearly two-fifth of the women (37\%) were poor.

Table I

Background characteristics of respondents

\begin{tabular}{|c|c|c|c|}
\hline Variables & Attributes & Percent & Number \\
\hline \multirow{3}{*}{$\begin{array}{l}\text { Women's autonomy in household } \\
\text { decision }\end{array}$} & No autonomy & 27.5 & 2713 \\
\hline & $\begin{array}{l}\text { Moderate autonomy (involved in I- } \\
2 \text { issues) }\end{array}$ & 34.8 & 3440 \\
\hline & $\begin{array}{l}\text { High autonomy (involved in all } 3 \\
\text { issues) }\end{array}$ & 37.7 & 3722 \\
\hline \multirow{3}{*}{ Age group } & Less than 25 years & 24.2 & 2389 \\
\hline & $25-34$ & 37.3 & 3683 \\
\hline & 35 or above & 38.5 & 3803 \\
\hline \multirow{4}{*}{ Ethnicity } & Brahmin/Chhetri & 31.1 & 3073 \\
\hline & Janajatis & 34.5 & 3408 \\
\hline & Dalit & 12.8 & 1265 \\
\hline & Other & 21.6 & 2129 \\
\hline \multirow{3}{*}{ Education } & No education & 40.3 & 3984 \\
\hline & Primary & 18.8 & 1853 \\
\hline & Secondary or above & 40.9 & 4038 \\
\hline \multirow{4}{*}{ Religion } & Hindu & 86.6 & 8552 \\
\hline & Buddhist & 4.7 & 463 \\
\hline & Muslim & 5.1 & 505 \\
\hline & Kirat/Christian & 3.6 & 355 \\
\hline \multirow{7}{*}{ Province } & Province I & 16.8 & 1655 \\
\hline & Province 2 & 22 & 2168 \\
\hline & Province 3 & 19.4 & 1920 \\
\hline & Gandaki (Province 4) & 9.6 & 950 \\
\hline & Province 5 & 17.7 & 1749 \\
\hline & Karnali (Province 6) & 5.9 & 586 \\
\hline & Province7 & 8.6 & 846 \\
\hline \multirow{2}{*}{ Place of residence } & Urban & 61.1 & 6031 \\
\hline & Rural & 38.9 & 3844 \\
\hline \multirow{4}{*}{ Desire for more children } & Wants within 2 years & 10.4 & $|03|$ \\
\hline & Wants after $2+$ years & 13.7 & 1355 \\
\hline & Unsure timing/undecided & 2.8 & 275 \\
\hline & Wants no more/Sterilized/infecund & 73 & 7213 \\
\hline \multirow{2}{*}{ Currently residing with husband } & Staying elsewhere & 34 & 3353 \\
\hline & Living with her & 66 & 6521 \\
\hline \multirow{2}{*}{$\begin{array}{l}\text { Heard FP information on radio in } \\
\text { the last few months }\end{array}$} & No & 66.1 & 6526 \\
\hline & Yes & 33.9 & 3348 \\
\hline
\end{tabular}




\begin{tabular}{llrr}
\hline Variables & Attributes & Percent & Number \\
\hline WatchedFP related information on & No & 66.7 & 6586 \\
TV over last few months & Yes & 33.3 & 3289 \\
\hline ReadFP information in & No & 89.1 & 8802 \\
newspaper/magazine in last few & Yes & 10.9 & 1072 \\
months & No & 41.1 & 4060 \\
\hline \multirow{2}{*}{ Currently working } & Yes & 58.9 & 5815 \\
\hline \multirow{2}{*}{ Wealth index } & Poor & 36.8 & 3632 \\
& Middle & 21.1 & 2088 \\
& Rich & 42.1 & 4154 \\
\hline
\end{tabular}

\section{Currently Married Women and Non-use of Contraception}

Bivariate analysis showed significant association of non-use of contraception with women's autonomy, age group, ethnicity, education, religion, province and place of residence, desire for more children, current living status with husband, awareness on FP from radio, TV and newspaper,working status and wealth index. Current non-use of family planning was significantly higher among women with no autonomy in household decision making $(57 \%)$ compared to those who had either moderate autonomy $(41 \%)$ or high autonomy $(47 \%)$ $(p<0.00 I)$. Non-use of FP was inversely proportional to age $(71 \%$ among women who were less than 25 years, $48 \%$ among $25-34$ years old and $32 \%$ in 35 years or above, $p<0.00$ I) which was also statistically significant. Similarly, current non use of family planning was significantly higher among women who were illiterate $(42 \%, \mathrm{p}<0.00 \mathrm{I})$, Dalit $(52 \%)$ orMuslim $(70 \%)$ $(\mathrm{p}<0.00 \mathrm{l})$.

Likewise, in Table 2 a significantly higher percentage of women who lived in Province 2, Province 4 and Province 5 (52\% each) were currently not using any of the family planning methods than their counterparts $(\mathrm{p}<0.00 \mathrm{l})$. Likewise, a significantly higher percentage of women residing in rural areas $(51 \%)$ were current non users of family planning than their comparison group $(\mathrm{p}<0.00 \mathrm{I})$. A significantly higher percentage of the women who wanted to have children within 2 years (87\%) than women who were unsure about the timing (yet to decide when to give birth, $67 \%$ ) and who desired children after 2 years $(66 \%)$ were currently not using any family planning methods $(\mathrm{p}<0.00 \mathrm{I})$. On the contrary, above three-fifth of the women (63\%) who wanted no more children/who were either sterile/infecund were still using family planning methods $(\mathrm{p}<0.00 \mathrm{I})$. A significantlyhigher percentage of women who were staying away from their husband (76\%) were current non-users of FP than their counterparts $(p<0.00 \mathrm{I})$.Almost a half $(49 \%)$ respondents who had heard information related to family planning over the last few months from radio did not use contraception for birth control $(p<0.00 \mathrm{I})$. Likewise, nearly the same percentage of the respondents who had gained FP from TV over the last few months did not use contraception $(p<0.00 \mathrm{I})$. In the same way, 48 percent of the respondents who had read information regarding family planning from newspaper or magazine within few months did not use contraceptives $(p<0.00 \mathrm{l})$. Role of field workers did not seem to influence the utilization of contraceptives. Fifty-five percent of the married women who were working did not use family planning methods $(p<0.00 I)$. Similarly, more than a half of the married women who belonged to middle wealth status did not use contraception $(\mathrm{p}<0.00 \mathrm{I})$, seeTable 2 . 
Table 2

Currently married women and non-use of contraception

\begin{tabular}{|c|c|c|c|c|}
\hline \multirow[t]{2}{*}{ Variables } & \multicolumn{2}{|c|}{ Use of Contraception (\%) } & \multicolumn{2}{|c|}{ Total } \\
\hline & $\begin{array}{l}\text { Use any } \\
\text { method }\end{array}$ & $\begin{array}{c}\text { Currently } \\
\text { non-use }\end{array}$ & $\%$ & $\mathbf{N}$ \\
\hline \multicolumn{5}{|c|}{ Women's autonomy in household decision $* * *$} \\
\hline No autonomy & 43.0 & 57.0 & 100 & 2713 \\
\hline Moderate autonomy (involved in I-2 issues) & 59.2 & 40.8 & 100 & 3440 \\
\hline High autonomy (involved in all 3 issues) & 53.5 & 46.5 & 100 & 3722 \\
\hline \multicolumn{5}{|c|}{ Age group $* * *$} \\
\hline Less than 25 years & 29.4 & 70.6 & 100 & 2389 \\
\hline $25-34$ & 51.8 & 48.2 & 100 & 3683 \\
\hline 35 or above & 68 & 32 & 100 & 3803 \\
\hline \multicolumn{5}{|c|}{ Ethnicity $* * * *$} \\
\hline Brahmin/Chhetri & 54.3 & 45.7 & 100 & 3073 \\
\hline Janajatis & 56.9 & 43.1 & 100 & 3408 \\
\hline Dalit & 47.5 & 52.5 & 100 & 1265 \\
\hline Other & 46.2 & 53.8 & 100 & 2129 \\
\hline \multicolumn{5}{|c|}{ Education $* * *$} \\
\hline No education & 58.2 & 41.8 & 100 & 3984 \\
\hline Primary & 50.4 & 49.6 & 100 & 1853 \\
\hline Secondary or above & 48.1 & 51.9 & 100 & 4038 \\
\hline \multicolumn{5}{|c|}{ Religion $* * *$} \\
\hline Hindu & 54 & 46 & 100 & 8552 \\
\hline Buddhist & 47.4 & 52.6 & 100 & 463 \\
\hline Muslim & 30.4 & 69.6 & 100 & 505 \\
\hline Kirat/Christian & 56.4 & 43.6 & 100 & 355 \\
\hline \multicolumn{5}{|c|}{ Province $* * *$} \\
\hline Province I & 55.1 & 44.9 & 100 & 1655 \\
\hline Province 2 & 47.7 & 52.3 & 100 & 2168 \\
\hline Province 3 & 60.6 & 39.4 & 100 & 1920 \\
\hline Gandaki (Province 4) & 48.5 & 51.5 & 100 & 950 \\
\hline Province 5 & 48.0 & 52.0 & 100 & 1749 \\
\hline Karnali (Province 6) & 51.1 & 48.9 & 100 & 586 \\
\hline Province 7 & 57.3 & 42.7 & 100 & 846 \\
\hline \multicolumn{5}{|c|}{ Place of residence $* * *$} \\
\hline Urban & 54.8 & 45.2 & 100 & 6031 \\
\hline Rural & 49.2 & 50.8 & 100 & 3844 \\
\hline \multicolumn{5}{|c|}{ Desire for more children $* * *$} \\
\hline Wants within 2 years & 13.3 & 86.7 & 100 & 1031 \\
\hline Wants after $2+$ years & 33.7 & 66.3 & 100 & 1355 \\
\hline Unsure timing/undecided & 32.5 & 67.5 & 100 & 275 \\
\hline Wants no more/Sterilized/infecund & 62.5 & 37.5 & 100 & 7213 \\
\hline \multicolumn{5}{|c|}{ Currently residing with husband $* * *$} \\
\hline Staying elsewhere & 23.5 & 76.5 & 100 & 3353 \\
\hline Living with her & 67.6 & 32.4 & 100 & 6521 \\
\hline \multicolumn{5}{|c|}{ Heard family planning on radio last few months $* * *$} \\
\hline No & 51.2 & 48.8 & 100 & 6526 \\
\hline Yes & 55.4 & 44.6 & 100 & 3348 \\
\hline
\end{tabular}

Watched family planning on TV last few months *** 


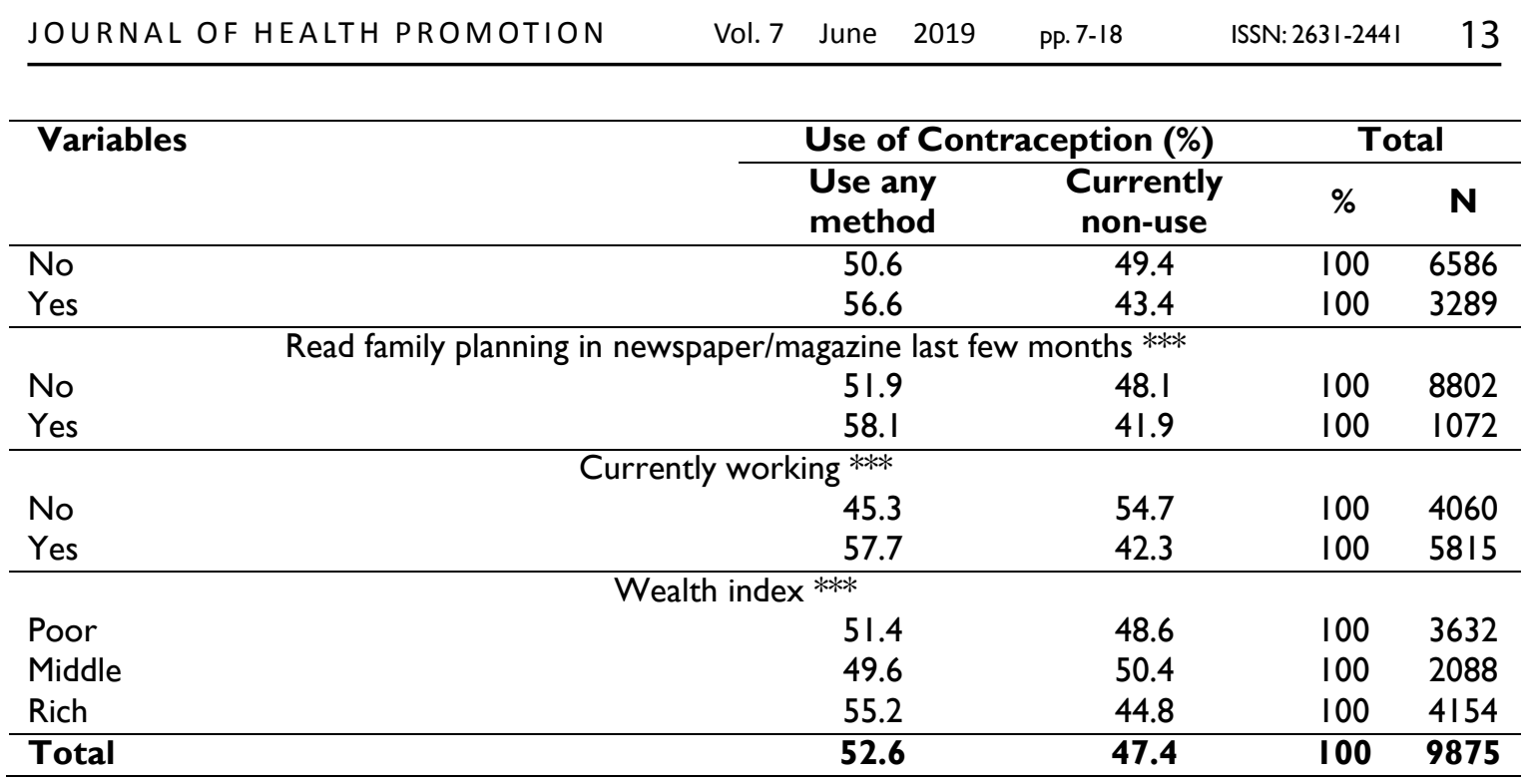

Note: significant at $* * *=p<0.001, N S=$ Not Significant

\section{Multivariate Analysis}

Adjusted odds ratios (aOR) werecalculated from multivariate logistic regression assessing the likelihood of non-use of contraception by selected socio-demographics andthree logistic models were run. Demographic and socio-economic characteristics such as age group, ethnicity, religion, porvince, place of residence, current working status, wealth index and women's autonomy in household decision were included. It is found that age of women, ethnicity, religion, province, currently living with husband, current working status, wealth index and women's autonomy in housheold decision were significant predictors for non-use of contraception. These variables are still significant predictors after adding desire for more children and exposure to mass media. Reduction of odds ratios in most of the variables in second and third modelsindicate that desire for more children and mass media exposure are also significant predictors for non use of contraception. In the third model, married women aged below25 years(aOR=2.07, 95\% Cl I.75-2.44) and aged 25-34 year $(\mathrm{aOR}=1.15,1.02-$ 1.29)were more likely to not use contraceptives compared to women over 34 . In case of ethnicity, Janajatis were more likely to use family planning methods compared to other castes.

Married women having no educationor primary level of education were more likely tonot use family planning methods compared to women having secondary or higher level of education. Muslim (aOR=2.45, 95\% Cl I.9-3.2) and Buddhist women (aOR= I.56, 95\% Cl I.23-I.97) were more likely to not usecontraception compared to higher caste Brahmin/Chhetri. Women from all other provinces were more likely to not useany contraceptive compared to Province 7.However, the relationship was significant only in Province $4(\mathrm{aOR}=1.47,95 \% \mathrm{Cl}$ I.17-1.86) and $5(\mathrm{aOR}=1.53,95 \% \mathrm{Cl} 1.25-1.88)$. Women who were not living together with their husband were more likely to not use family planning method than those who were living with their husband $(\mathrm{aOR}=7.3 \mathrm{I}, 95 \% \mathrm{Cl}$ 6.6-8.1). Women who had no autonomy in household decision making were more likely to not use contraceptives $(a O R=1.16,95 \% \mathrm{Cl} I .01-1.32)$ while women having some autonomy were less likely to not usefamily planning methods $(\mathrm{aOR}=0.88$, 95\% Cl .78-.99) compared to women having high autonomy.Job for women seems a predictor for utilization of family planning devices. Women who did not work currently were more likely 
to not use contraceptives compared to women currently working $(\mathrm{aOR}=1.47,95 \% \mathrm{Cl} 1.32-$ I.63). Similarly, women with poor wealth status were more likely to not use contraception compared to rich women $(\mathrm{aOR}=1.16,95 \% \mathrm{Cl} 1.02-1.3 \mathrm{I})$. Women who wanted to have a child within two years were more likely to not usecontraception compared to the women who wanted no more children ( $\mathrm{aOR}=10.74,95 \% \mathrm{Cl}$ 8.7-13.2).

Exposure to mass media such as radio, TV and newspapers seemed to influence use of contraception. Currently married women of reproductive age who had heard/watched family planning related information from TV were more likely to not use contraception $(a O R=1.16$, $95 \% \mathrm{Cl}$ I.02-I.3I).

Table 3

Multivariate analysis of socio-demographics currently married women and non-use of contraception

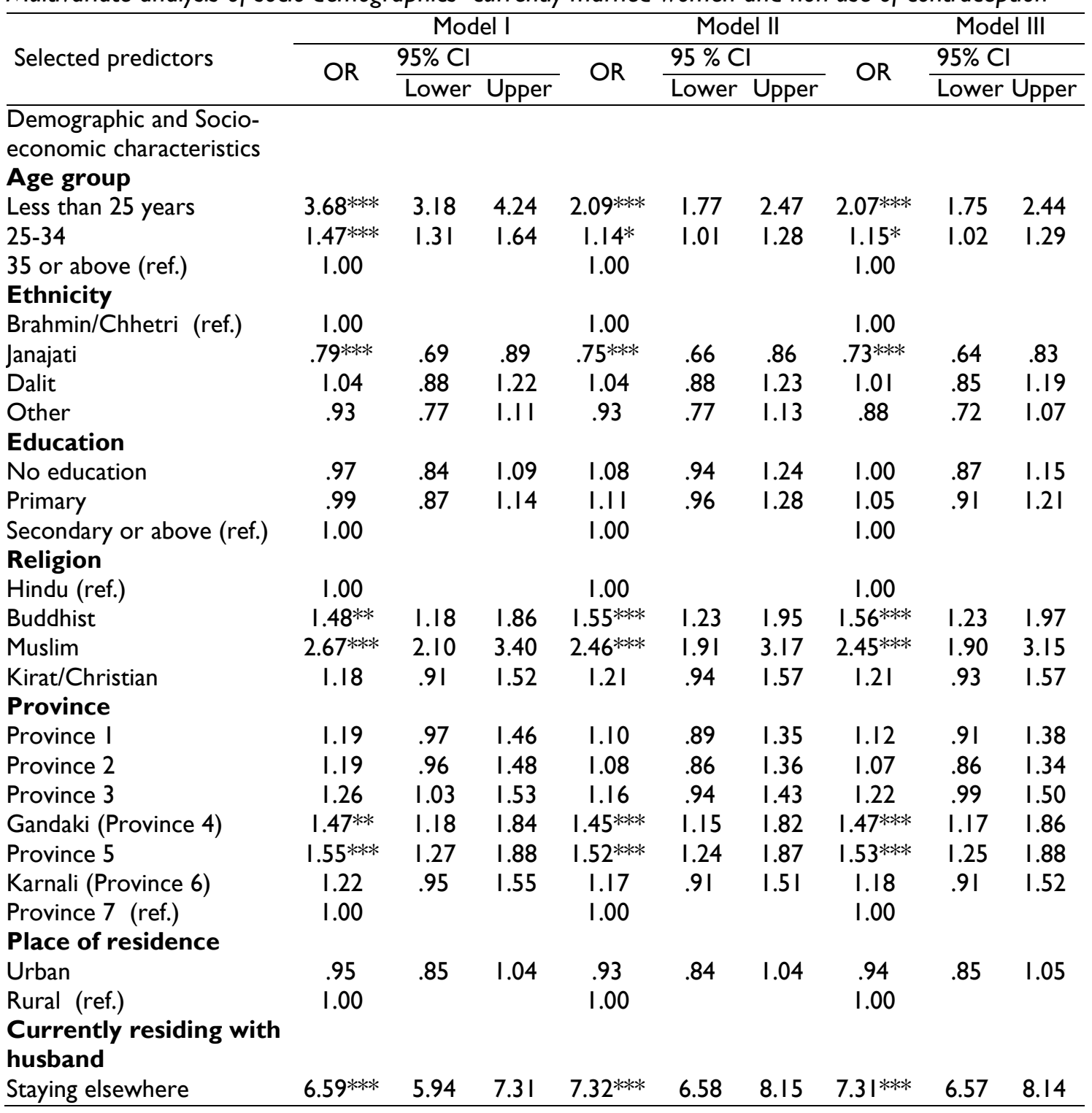




\begin{tabular}{|c|c|c|c|c|c|c|c|c|c|}
\hline \multirow{3}{*}{ Selected predictors } & \multicolumn{3}{|c|}{ Model I } & \multicolumn{3}{|c|}{ Model II } & & \multicolumn{2}{|c|}{ Model III } \\
\hline & \multirow{2}{*}{ OR } & \multicolumn{2}{|l|}{$95 \% \mathrm{Cl}$} & \multirow{2}{*}{ OR } & $95 \% \mathrm{Cl}$ & & \multirow{2}{*}{ OR } & \multicolumn{2}{|c|}{$95 \% \mathrm{Cl}$} \\
\hline & & Lower & Upper & & Lower & Upper & & \multicolumn{2}{|c|}{ Lower Upper } \\
\hline Living with her (ref.) & 1.00 & & & 1.00 & & & 1.00 & & \\
\hline \multicolumn{10}{|l|}{ Currently working } \\
\hline No & $1.44^{* * *}$ & 1.30 & 1.59 & $1.48 * * *$ & 1.33 & 1.64 & $1.47 * * *$ & 1.32 & 1.63 \\
\hline Yes (ref.) & 1.00 & & & 1.00 & & & 1.00 & & \\
\hline \multicolumn{10}{|l|}{ Wealth index } \\
\hline Poor & $1.15^{*}$ & 1.01 & 1.29 & $1.21 * *$ & 1.06 & 1.37 & $1.15^{*}$ & I.0I & 1.31 \\
\hline Middle & 1.00 & .87 & 1.14 & I.0I & .88 & 1.15 & .99 & .86 & 1.13 \\
\hline Rich (ref.) & 1.00 & & & 1.00 & & & 1.00 & & \\
\hline \multicolumn{10}{|l|}{$\begin{array}{l}\text { Women's autonomy in } \\
\text { household decision }\end{array}$} \\
\hline No autonomy & $1.32^{* * *}$ & 1.16 & 1.49 & $1.18 *$ & 1.03 & I.34 & $1.16 *$ & I.0I & 1.32 \\
\hline $\begin{array}{l}\text { Moderate autonomy } \\
\text { (involved in I-2 issues) }\end{array}$ & .92 & .82 & 1.02 & $.88 *$ & .78 & .98 & $.88^{*}$ & .78 & .99 \\
\hline $\begin{array}{l}\text { High autonomy (involved } \\
\text { in all } 3 \text { issues) (ref.) }\end{array}$ & 1.00 & & & 1.00 & & & 1.00 & & \\
\hline \multicolumn{10}{|l|}{ Desire for more children } \\
\hline Wants within 2 years & & & & $10.61 * * *$ & 8.64 & 13.04 & $10.73^{* * *}$ & 8.72 & 13.19 \\
\hline Wants after $2+$ years & & & & $1.87 * * *$ & 1.59 & 2.21 & $1.89 * * *$ & 1.60 & 2.23 \\
\hline Unsure timing/undecided & & & & $2.7 \mid * * *$ & 2.02 & 3.62 & $2.70 * * *$ & 2.02 & 3.62 \\
\hline Wants no & & & & & & & 1.00 & & \\
\hline $\begin{array}{l}\text { more/Sterilized/infecund } \\
\text { (ref.) }\end{array}$ & & & & 1.00 & & & & & \\
\hline \multirow{2}{*}{\multicolumn{10}{|c|}{$\begin{array}{l}\text { Mass media Exposure } \\
\text { Heard FP on radio last } \\
\text { few months }\end{array}$}} \\
\hline & & & & & & & & & \\
\hline No & & & & & & & 1.10 & .98 & 1.23 \\
\hline Yes (ref.) & & & & & & & 1.00 & & \\
\hline \multicolumn{10}{|l|}{$\begin{array}{l}\text { Heard FP on TV last } \\
\text { few months }\end{array}$} \\
\hline No & & & & & & & $1.16 *$ & 1.02 & 1.31 \\
\hline Yes (ref.) & & & & & & & 1.00 & & \\
\hline \multirow{2}{*}{\multicolumn{10}{|c|}{$\begin{array}{l}\text { Heard FP in } \\
\text { newspaper/magazine } \\
\text { last few months }\end{array}$}} \\
\hline & & & & & & & & & \\
\hline No & & & & & & & 1.13 & .95 & 1.35 \\
\hline Yes (ref.) & & & & & & & 1.00 & & \\
\hline Constant & $0.201 * * *$ & & & $0.180 * * *$ & & & $0.147 * * *$ & & \\
\hline-2 Log likelihood & 10987.0 & & & 10319.1 & & & 10302.7 & & \\
\hline Cox \& Snell R Square & 0.237 & & & 0.287 & & & 0.288 & & \\
\hline
\end{tabular}

Note: significant at $*=p<0.05, * *=p<0.01, * * *=p<0.00$

\section{Discussion}

Our analysis shows significant associations between exposure to mass media like radio, TV and newspapers and non-use of contraceptives. Nearly the same result was observed in the USA. Research respondents in the United States whohad low level of education, ethnicity/caste (being black), age group of 35 to 44 years, infrequent sexual intercourse, were not currently married or in a relationship, dissatisfied with currently used method and who had lack of 
access to contraceptive method were more likely to non-use of contraceptives(Frost, Singh, \& Finer, 2004). A randomized control trial in Nepal in 1994 to 1996 showed that practice of individual health education has slightly enhancedthe uptake of FP methods.Therefore, mass media may be suitable for disseminating information related to FP to the women of reproductive age (Bolam, Manandhar, Shrestha, Ellis, \& Costello, 1998).

NDHS (2006) indicates that there were three main reasons for non-use of contraception. First, fertility-related causes such as infrequent sexual intercourse, menopause, sub-fecund or in-fecund and desire for more child; secondly, method related causes such as health concerns, fear of side effects, lack of access and inconvenience to use of contraceptives and thirdly reason was opposition to FP methods such as respondent's opposition, husband's opposition and religious prohibition (Tamang, Subedi, \& Packer, 2010). While NDHS 2016 shows that the causes of discontinuation of contraceptive methods were husband not living together (47\%), side effects or health concerns $(18 \%)$ and desire for children $(13 \%)$ and others (Ministry of Health; New ERA; \& ICF, 20I7).

Service providers' knowledge and attitudes are also important for clients. A study shows that overall services providers' knowledgeon FP methods was low. Service providers were thereforerecommended for additional training to support and improve their knowledge on family planning methods and itsside-effects management (Chakraborty, Murphy, Paudel, \& Sharma, 2015). Inadequate knowledge and training of health personals; low level of education; extremes of reproductive age and parity; fear of side effects; lack of knowledge of the clients and lack of partner's consent were associated with non-use of contraceptives in the context of Nigeria (Aghoja et al., 2009). Similarly, exposure to information from mass media, educational level, and family size were predictors for use or non-use of contraceptive (Okezie, Ogbe, \& Okezie, 2010).

Some barriers are identified as factors hindering for FP service utilization. Psychosocial barriers, i.e. an opposition to utilize the service due to religion, husband's opposition or personal non-religious reasons were the main barriers followed by economic, cognitive, and physical barriers for the utilization of family planning services (Stephenson \& Hennink, 2004).Likewise, lack of awareness about maternal health services, underutilization of maternal health services, social disparities in maternal health are main barriers to utilize health service including family planning service in Nepal (Ranabhat et al., 2019). Therefore, these barriers should be addressed timely to meet the targets of the family planning as well as reproductive health.

\section{Conclusion}

Almost a half of the sampled currently married women were non-users of contraception. Socio-demographic factors such as women's autonomy in decision making, age less than 25 years, Dalits and Muslims, residents of provinces 2,4 and 5, living in rural areas, uncertain about timing of pregnancy, husbandnot living together, jobless, poor and middle level wealth index, and non-exposure to FP related information from TVwere the major predictors for the nonuse of contraception among currently married women of reproductive age.Thus, FP interventions need to be more focused among younger aged women, poor and jobless women, rural women and women having low or no education. Furthermore, women empowerment initiatives (education and employment opportunities) tied up with family planning programs 
would be beneficial to increase contraceptive uptake among married women of reproductive age.

\section{Acknowledgments}

The authors thanks MEASURE DHS + for providing access to the data. The authors also like to thanks to the reviewers for their valuable suggestions.

\section{References}

Acharya, L. B. (2002). First method of family planning: a neglected information by health planners and service providers in Nepal. Popline: The Knowledge for Health (K4Health). Retrieved from https://www.popline.org/node/246326

Aghoja, C. O., Okonofua, F. E., Umueri, C., Otayohwo, R., Onowhakpor, E. A., \& Inikori, K. A. (2009). Factors associated with the knowledge, practice and perceptions of contraception in rural southern Nigeria. Ghana Medial Journal, 43(3), II 5-121.

Akinlo, A., Bisiriyu, A., \& Esimai, O. (2013). Influence of Use of Maternal Health Care on Postpartum Contraception in Nigeria (DHS Working Paper Number 92). Calverton, Maryland.

Bolam, A., Manandhar, D. S., Shrestha, P., Ellis, M., \& Costello, A. M. D. L. (1998). The effects of postnatal health education for mothers on infant care and family planning practices in Nepal: a randomised controlled trial. BMJ, 3/6, 805-8II.

Chakraborty, N. M., Murphy, C., Paudel, M., \& Sharma, S. (2015). Knowledge and perceptions of the intrauterine device among family planning providers in Nepal: a cross-sectional analysis by cadre and sector. BMC Health Services Research, 15(39), I-14. http://doi.org//0.1 I86/s I2913-015-070I-y

Chaudhary, T. K., Dangol, B. K., Rai, L., \& Rai, M. K. (20/6). Predictors of Use of Contraception among Married Women of Reproductive Age in a Rural Area of Nepal. Journal of Advanced Academic Research, 3(III), 89-99.

Department of Health Services. (2018). Annual Report FY 2073/74 (2016/17). Kanthmandu. Retrieved from http://dohs.gov.np/wp-content/uploads/2018/04/ Annual_Report_207374.pdf

Frost, J. J., Singh, S., \& Finer, L. B. (2004). Factors associated with contraceptive use and nonuse, United Atates, 2004. Perspectives on Sexual and Reproductive Health, 39(2), 90-99. http://doi.org// 0.1363/3909007

Government of Nepal, \& Department of Health Services. (2018). Annual Report: Department of Health Services 2073/74(20/6//7). Kathmandu. Retrieved from http://dohs.gov.np/wpcontent/uploads/2018/04/Annual_Report_2073-74.pdf

Health Policy Project. (n.d.). Family planning in Nepal: Saving lives and improving health. Washington, DC: USAID; GoN, MoHP and Health Policy Project.

Hutchinson, P., \& Wheeler, J. (2006). Advanced Methods for Evaluating the Impact of Family Planning Communication Programs: Evidence from Tanzania and Nepal. Sudies in Family Planning, 37(3), 169-186.

Kafle, R. B., Dulal, K. P., \& Pandey, K. P. (2017). Continuum of Maternal Health Care and the Use 
of Postpartum Family Planning in Nepal (No. DHS Working Paper Nol33). Maryland, USA.

Korra, A. (2002). Planning and Reasons for Nonuse among Women with Unmet Need for Family Planning in Ethiopia. Calverton, Maryland: ORC Macro.

Ministry of Health; New ERA; \& ICF. (2017). Nepal Demographic and Health Survey 2016. Kathmandu, Nepal: Ministry of Health, Nepal.

Ministry of Health (MoH). (20I7). National Health Policy, 2017 - First Draft, I-39. Retrieved from http://dohs.gov.np/wp-content/uploads/2014/04/NHP-2074_policy-0I.pdf

National Health Sector Programme. National Health Policy 2014 (2014). Nepal. Retrieved from http://nhsp.org.np/wp-content/uploads/2016/08/New-health-policy-2014-Unofficialtranslation.pdf

Nepal Law Commission. (n.d.). Constitution of Nepal 20/5. Retrieved from http://www.lawcommission.gov.np/en/documents/2016/0l/constitution-of-nepal-2.pdf

Okezie, C. A., Ogbe, A. O., \& Okezie, C. R. (20/0). Socio-economic determinants of contraceptive use among rural women in Ikwuano Local Government Area of Abia State, Nigeria. International NGO Journal, 5(4), 74-77.

Stephenson, R., \& Hennink, M. (2004). Barriers to Family Planning Service use among the Urban Poor in. Asia Pacific Population Journal, 19(2), 5-26. Retrieved from https://scholar.google.com/scholar?hl=en\&as_sdt=0\%2C5\&q=Barriers+to+Family+Plannin g+Service+use+among+the+Urban+Poor+in+Pakistan\&btnG=

Sutherland, E. G. (1994). Quality of Family Planning Services and Contraceptive Use Dynamics among Limited Mobility Populations in the Western Chitwan Valley of Nepal. Retrieved from http://www.demoscope.ru/weekly/knigi/tours_2005/ papers/iussp2005s5 I558.pdf

Tamang, A., Subedi, G., \& Packer, C. (2010). The status of family planning and reporductive health. Kathmandu: Center for Research on Environment Health and Population Activities [CREHPA].

Tuladhar, H., \& Khanal, R. M. (2008). Awareness and practice of family Planning methods in women attending Gyne OPD at Nepal Medical College Teaching Hospital. Nepal Medical College Journal, 10(3), |84-191. 